\section{Host molecular factors and viral genotypes in the mother- to-child HIV-1 transmission in sub-Saharan Africa}

\author{
Linda Chapdeleine M. Mouafo, ${ }^{1,2}$ \\ Béatrice Dambaya, 2,3 \\ Nicole N. Ngoufack, 2,4 \\ Céline N. Nkenfou ${ }^{2,5}$ \\ ${ }^{1}$ Department of Biochemistry, University \\ of Dschang, ${ }^{2}$ Systems Biology \\ Laboratory, Chantal BIYA International \\ Reference Centre for Research on \\ HIV/AIDS Prevention and Management, \\ Yaoundé; ${ }^{3}$ Department of Animal \\ Sciences, University of Yaounde 1; \\ ${ }^{4}$ Department of Biochemistry, University \\ of Yaounde 1, ${ }^{5}$ Higher Teachers' \\ Training College, University of Yaounde \\ 1, Cameroon
}

\begin{abstract}
Maternal viral load and immune status, timing and route of delivery, viral subtype, and host genetics are known to influence the transmission, acquisition and disease progression of human immunodeficiency virus-1 (HIV-1) infection. This review summarizes the findings from published works on host molecular factors and virus genotypes affecting mother to child transmission (MTCT) in Africa and identifies the gaps that need to be addressed in future research. Articles in PubMed, Google and AIDSearch and relevant conference abstracts publications were searched. Accessible articles on host factors and viral genetics impacting the MTCT of HIV, done on African populations till 2015 were downloaded. Forty-six articles were found and accessed; 70\% described host genes impacting the transmission. The most studied gene was the CCR 5 promoter, followed by the CCR2-64I found to reduce MTCT; then $S D F 1-3$ 'A shown to have no effect on MTCT and others like the DC-SIGNR, CD4, CCL3 and IP10. The HLA class I was most studied and was generally linked to the protective effect on MTCT. Breast milk constituents were associated to protection against MTCT. However, existing studies in Sub Saharan Africa were done just in few countries and some done without control groups. Contradictory results obtained may be due to different genetic background, type of controls, different socio-cultural and economic environment and population size. More studies are thus needed to better understand the mechanism of transmission or prevention.
\end{abstract}

\section{Introduction}

More than three decades after the discovery of HIV/AIDS, progress has been made in understanding the pathogenesis, treatment and transmission of HIV and the factors influencing the risk of mother-tochild transmission, but most importantly progress has been made in the interruption of HIV-1 mother-to-child transmission. ${ }^{1}$ However, despite these advances many challenges remain to eliminate MTCT and in optimizing antiretroviral therapy for pregnant women and children in developing countries. $^{2,3}$

Furthermore, HIV-1 vaccine failures ${ }^{4-6}$ demonstrate the need to further understand the interactions between host and virus, and particularly in Africa, where the high burden, and the high level diversity of the HIV strains are no more to be shown. ${ }^{7}$

Millions of children worldwide acquire HIV/AIDS as a result of mother-to-child transmission during pregnancy, delivery or breastfeeding. ${ }^{8}$ This is the primary routes of infection of children under the age of 15 years. At the end of 2014, 2.6 (2.6-3.2) million children under the age of 15 years were estimated to be living with HIV/AIDS, with about 220,000 (180,000-250,000) new HIV infections. The rate of transmission of HIV is still high in African countries. ${ }^{9}$

Despite the fact that progress has been achieved in the development and implementation of strategies designed to reduce the level of MTCT, in developing countries, pregnant HIV infected mothers still have limited access to anti-retroviral drugs as it is the case in Cameroon. ${ }^{10}$ The identification of genetic markers associated with transmission can help define risk factors associated to MTCT and provide new insights into HIV-1 pathogenesis leading to new treatments and new immunologic targets for vaccine development. In this review, we summarize the available data on the impact of host genetics on MTCT of HIV/AIDS that have been done on African populations (Table 1), ${ }^{11-28}$ and other factors that may play a role in understanding MTCT of HIV/AIDS. Where appropriate, the differences between findings in the low and middle income countries and developed countries were discussed.

\section{Materials and Methods}

For the writing of this narrative literature review, we searched for articles or publications in PubMed, EMBASE, Google and AIDSearch. Relevant conference abstracts publications were also fully down-
Correspondence: Céline N. Nkenfou, Chantal BIYA International Reference Centre for Research on HIV/AIDS Prevention and Management, P.O. 3077 Yaoundé-Messa, Cameroon.

Tel.: +237675573519 - Fax: +237.222.315456.

E-mail: nkenfou@yahoo.com

Key words: HIV-1; mother to child transmission; Sub Saharan Africa; host factors; viral genetics.

Acknowledgements: authors would like to thank the CBIRC for the support provided.

Contributions: LCM: data collection, analysis, interpretation and manuscript preparation; $\mathrm{BD}, \mathrm{NNN}$ : data interpretation and critical revision of the manuscript; $\mathrm{CNN}$ : design, analysis, interpretation and manuscript revision and approval.

Conflict of interest: the authors declare no potential conflict of interest.

Received for publication: 19 August 2016. Accepted for publication: 2 May 2017.

This work is licensed under a Creative Commons Attribution NonCommercial 4.0 License (CC BY-NC 4.0).

(C) Copyright L.Ch.M. Mouafo et al., 2017 Licensee PAGEPress, Italy

Journal of Public Health in Africa 2017; 8:594 doi:10.4081/jphia.2017.594

loaded.Terms used in the research consist of the following key word: HIV transmission; mother; child; Africa; HIV acquisition, host genes; host factors; pediatric. Some terms were used as composed-word such as: mother to child transmission; host factors in HIV transmission. The language of articles used in this review was French and English. We selected all articles that were accessible regarding the host factors and viral genetics impacting the mother to child transmission of HIV/AIDS, done on African populations till 2015.

\section{Polymorphism in chemokine receptors: importance on viral entry to the host cell}

To enter a target cell, HIV interacts with the CD4 receptor via its gp120 protein, thereby inducing a conformational change in this protein, which exposes a portion of trans-membrane glycoprotein gp41, and allows access of the gp120 V-loop to either CCR5 or CXCR4 as co-receptor. Subsequent events allow the viral capsid to 
enter the target cell. ${ }^{29}$ A number of genetic polymorphisms in the chemokine receptor system have been associated with HIV-1 acquisition and disease progression even single nucleotide polymorphisms in the untranslated regions of CCR5, RANTES and SDF-1. ${ }^{30,31}$ Several studies have been carried out to understand the association of these polymorphisms in the MTCT. In a work published in 2008 by Singh et al., the impact of CCR 5 promoter, CCR2, CX3CR 1 and SDF-1 polymorphisms on the risk of HIV-1 MTCT in three sub-Saharan African cohorts of infants (Malawi, South Africa and Uganda) was examined. A link between CCR5 promoter variants at positions 59029 and 59353 in infants and the risk for perinatal infection was found. Anti-retroviral naïve infants with the 59029A allele had a higher risk of MTCT versus $\mathrm{G} / \mathrm{G}$ infants. Exposure to anti-retrovirals modified the impact of these genetic variants on MTCT. Children with the CCR5-59029-A allele, known to be associated with higher expression of CCR5, were less susceptible to HIV infection when exposed to nevirapine. However, this same variant was associated with a higher risk for MTCT when zidovudine was given perinatally. Because CCR559029 and -59353 are in linkage disequilibrium, the associations between each of these polymorphisms and risk of transmission were similar. ${ }^{11}$ Another study reported that CCR5 SNPs -2459G and -2135T associated with reduced receptor expression can protect against MTCT of HIV at low mother viral loads (VL), whereas opposite effect may be observed with high mother VLs due to disproportionate co-receptor availability. ${ }^{12}$ For the CCR5-59356-C/T promoter variant, infants with the $\mathrm{T}$ allele had a lower rate of infection compared to infants with the C/C genotype. ${ }^{11-13}$ On the opposite, Kostrikis et al. (1999) reported that the T/T genotype was associated with a higher rate of MTCT in untreated motherinfant pairs in the United States, ${ }^{32}$ results that may be explained by the geographic difference.

Among 288 HIV-1-infected breastfeeding Kenyan women who received zidovudine prophylaxis and were followed with their infants in Nairobi, Katz et al. (2010) found no association between maternal genetic polymorphisms in CCR5 gene (59029G/A, 59353T/C, 59356T/C, 59402G/A) and HIV-1 transmission. Also no association was found between the genetic polymorphisms in CCR5 and plasma, cervical, and breast milk viral loads; or breast milk chemokine concentration. ${ }^{16}$ Mangano et al. (1998) reached the conclusion that the 32 bp deletion in CCR5 receptor was not associated to HIV-1 MTCT transmission. ${ }^{33}$ Approaches used to study the polymorphism may help to have a better understanding of the MTCT, a recent study suggest that the measurement of placental expression of CCR5 alone is not an adequate indicator of the risk of mother-tochild transmission of HIV. ${ }^{34}$

The presence of the CCR2-64I allele was associated with reduced viral load and with protection against early HIV-1 transmission among pregnant women who received short course zidovudine. ${ }^{14}$ This corroborated with the protective effects of $C C R 2-A / A$ genotype found in Argentinean children born to HIV-1 infected mothers, ${ }^{33}$ while Teglas et al. (1999) and Brouwer et al. (2005) failed to find any association of the $C C R 2$ genotype with perinatal transmission in France and Western Kenya, respectively. ${ }^{15,35}$ The work of Singh et al. (2008) revealed that the $C C R 2-A / A$ genotype was associated with higher risk of transmission versus $\mathrm{G}$ allele carriers indicating a moderate effect of CCR2 genotypes on MTCT in mother-infant pairs in sub-Saharan Africa.

Other receptors interacting with HIV-1 have been studied. A study has demonstrated for the first time the potential functional impact of DC-SIGNR mutations on its expression in the placenta and in vertical transmission of HIV-1. Authors suggested that the presence of DC-SIGNR at the placental endothelial cell surface may protect infants from HIV-1 infection by capturing virus and promoting its degradation. However, in case of low levels of DCSIGNR, HIV-1 would preferentially binds CCR5 on endothelial cells resulting in a loss of placental barrier integrity and enhancing passage of maternal HIV1infected cells in fetal circulation, resulting in MTCT of HIV-1. ${ }^{18}$ It is worth mentioning that these receptors also bind the HIV-1 gp120 to enhance trans-infection of T cells, but they are not co-receptors for viral entry into target cells. ${ }^{36}$

For the CD4 gene, Kenyan children, heterozygotes for the C868T polymorphism (C868T) may be twice at risk of MTCT. ${ }^{19}$ This same mutation had apparently no effect when expressed in the mother.

\section{Polymorphism in chemokine nat- ural ligands for HIV co-receptors}

Co-receptors used by HIV-1 to infect new cells are naturally receptors for their host ligand, which most of the times are chemokines. The chemokine receptor-ligand interactions represent a barrier to HIV1 binding to its co-receptors, hence inhibiting the entry of the HIV into the cells.

The presence of the $S D F-1-A$ allele in infants implies no impact on MTCT. ${ }^{11}$ It is likely that if $S D F-1-A$ alters MTCT, its relatively low frequency limits its impact at population basis. Also, Katz et al. (2010) found no association between $S D F-13^{\prime}$ G801A and mother-to-child HIV-1 transmission. But the maternal, and not the infant SDF1-3'G/A genotype has been found associated with increased risk of HIV-1 MTCT, particularly through breastfeeding, and the infant allele had no effect on mother-to-child transmission. ${ }^{17}$

CCL3 is one of the natural ligands for CCR5, utilized by R5 HIV-1 virus as coreceptor for viral entry. The fact that the $\mathrm{CC}$ chemokines could block macrophage tropic HIV-1 viruses from replicating in vitro raised the possibility that these molecules may contribute to protective immunity against HIV-1 in vivo. ${ }^{37} \mathrm{~A}$ study based on gene copy number (GCN) done by Meddows-Taylor et al. in (2006) have shown that at equivalent CCL3L1 GCN, CCL3 production is lower in HIV-1-infected children than in uninfected children exposed to perinatal HIV-1 transmission. ${ }^{20}$ This raised the possibility of non functional CCL3 gene copies occurring in the former, implying the limited ability of infants to produce $C C L 3$, thus associated to increased susceptibility to perinatal HIV-1 transmission. The same observation has been made in a study by Kuhn et al. (2007) but here the exposure to nevirapine will imply a controversial observation suggesting that nevirapine may have direct or indirect effects that partly modify the role of the CCR5 ligand CCL3 in HIV transmission. ${ }^{21}$

IP-10, also known as CXCL10, is a type 1 chemokine that binds to the CXCR3 receptor $^{38}$ and attracts Th1 lymphocytes, monocytes, eosinophils, and dendritic cells, many of which are infectible by HIV-1 infection and replication. IP-10 levels in the plasma have been shown to be independently correlated with in utero MTCT of HIV $-1 .{ }^{39}$

\section{Polymorphism associated to the binding affinity of anti-HIV anti- body}

Single nucleotide polymorphisms (SNPs) in host Fc gamma receptors (Fc $\gamma \mathrm{Rs}$ ) of antibodies can affect IgG binding affinity and alter the ability of effector cells bearing Fc $\gamma R$ s to facilitate Fc-mediated antibody functions. ${ }^{40,41}$ The polymorphism SNP rs1801274 in FCGR2A and SNP rs396991 in FCGR3A have been found not to be associated with infant HIV infection. In mothers, FCGR2A genotype did not influence transmission risk, but there was 
evidence of FCGR3A genotype impacting early postpartum MTCT. ${ }^{22}$ A study in Kenya provides the first evidence that the infant Fc gamma RIIa His/His131 genotype is associated with susceptibility to perinatal HIV-1 transmission and further suggests that there is a dose-response relationship for the effect of the FC gamma RIIa His131 gene on transmission. ${ }^{23}$

\section{HLA polymorphism have an impact on the outcome of MTCT}

HLA class I and class II alleles are the most polymorphic genes in Humans. ${ }^{42}$ They are currently 14,409 HLA and related alleles, more than 220 genes of diverse function including highly polymorphic antigen-presenting proteins. HLA genes are among the first genetic markers found to alter the risk of becoming infected with HIV-1 and the rate of disease progression. ${ }^{43,44}$ HLA class 1 is the most studied between the two classes, mainly due to his implication in the mechanism of HIV-1 infection. HLA $B^{*} 18$ may protect breast-fed infants against both early and late HIV-1 acquisition in a Kenyan perinatal cohort, ${ }^{25}$ also $H L A-B * 44$ may be associated with the resistance to HIV infection upon mother to child exposure found in a Cameroonian children population, ${ }^{26}$ as well a more specific genotype have shown that among infants the $A * 2 / 6802$ super-type is associated with an estimated 7-fold protective effect from perinatal HIV-1 transmission. ${ }^{27}$ In contrary HLA class 1 concordance between a mother and her infant and the homozygosity of the maternal HLA is associated with increased of overall risk, ${ }^{24}$ while HLA discordance decreases the risk of MTCT. ${ }^{45}$ The 14bp insertion in HLA-G was associated with protection from in utero and intrapartum HIV infection in children in Zambia, suggesting that $H L A-G$ could be involved in the vertical transmission of HIV, ${ }^{46}$ Mother-child HLA-G concordance was found not to be associated with the increased perinatal HIV transmission. Genome-wide association studies, interrogating 0.5-1 million SNPs, has not confirmed the HLA system as the main contributor to HIV-1 infection in children vertically exposed to HIV-1. ${ }^{47}$

Association studies of polymorphisms of HLA class II genes with HIV-1 MTCT are scarce. A study on a Kenyan population showed that DRB genotype concordance between mother and child increased risk of perinatal HIV transmission, whereas, DPA1, DPB1 and DQB1 concordance between mother and child had no significant influence on perinatal HIV transmission. In addition, DRB1*15:03 phenotype (mother or child) significantly increases the risk of perinatal HIV-1 transmission. Overall DRB1 discordance between mother and child provided 5 fold protection. However, the protective effect of DRB discordance was diminished if only one of the couple mother-baby carried the DRB1*15:03. DRB3 positive phenotype children were less likely to be infected perinatally. However, there was a 4 fold increase in risk of being infected at birth if DRB3+ children were born to DRB $1 * 15: 03+$ mother compared to those with DRB $1 * 15: 03$-mother. ${ }^{28}$

\section{Breast milk constituents may provide inside of the post-par- tum HIV-1 transmission}

Mother-to-child transmission of HIV can occur through breastfeeding. However, many breastfed infants do not acquire HIV1 despite continuous exposure to the virus from their mothers' milk over many months. This mode of transmission offers a unique in vivo model system to study associations between components of human milk and HIV transmission risk. ${ }^{48}$ Breast milk as any in vivo fluid is composed of many constituents that can influence or not the transmission. Lack of persistence of HIV-specific IgM in breast milk collected at 18 months was associated with a high risk

Table 1. Host genetics polymorphism impacting mother-to-child transmission (MTCT) in Africa.

\begin{tabular}{|c|c|c|c|c|c|}
\hline $\begin{array}{l}\text { Molecules / } \\
\text { gene }\end{array}$ & Polymorphism & $\begin{array}{l}\text { Effect } \\
\text { on MTCT }\end{array}$ & $\begin{array}{l}\text { Sample } \\
\text { type }\end{array}$ & $\begin{array}{l}\text { Population/ } \\
\text { Country }\end{array}$ & References \\
\hline CCR5 & $\begin{array}{l}\text { rs1799987 (-2459G, 59029) } \\
\text { rs1799988 (-2135T, 59353) } \\
\text { rs41469351 (-2132T, 59356) }\end{array}$ & $\begin{array}{l}\text { Increased/protect } \\
\text { Increased/protect } \\
\text { Dicrease }\end{array}$ & $\begin{array}{l}\text { Infants; Mothers and infants } \\
\text { Infants; Mothers and infants } \\
\text { Infants }\end{array}$ & $\begin{array}{l}\text { Malawi, South Africa and Uganda } \\
\text { Malawi, South Africa and Uganda } \\
\text { Malawi, South Africa and Uganda Kenya }\end{array}$ & $\begin{array}{l}(11,12) \\
(11,12) \\
(11,13)\end{array}$ \\
\hline CCR2 & CCR2-64I & $\begin{array}{l}\text { Protect } \\
\text { No effect }\end{array}$ & $\begin{array}{l}\text { Infants; mothers } \\
\text { Mothers }\end{array}$ & $\begin{array}{l}\text { Malawi, South Africa and Uganda } \\
\text { Western Kenya }\end{array}$ & $\begin{array}{l}(11,14) \\
(15)\end{array}$ \\
\hline SDF1 & $\sqrt{x+3}$ & $\begin{array}{l}\text { No effect } \\
\text { Increased }\end{array}$ & $\begin{array}{l}\text { Infants } \\
\text { Mothers and infants }\end{array}$ & $\begin{array}{l}\text { Malawi, South Africa and Uganda } \\
\text { Kenya }\end{array}$ & $\begin{array}{l}(11,16) \\
(17)\end{array}$ \\
\hline DC-SIGNR & $\begin{array}{l}\text { High concentration in the } \\
\text { placental endhothelial } \\
\text { High concentration in the placenta }\end{array}$ & $\begin{array}{l}\text { Protect } \\
\text { Increased }\end{array}$ & $\begin{array}{l}\text { Mothers and infants } \\
\text { Mothers and infants }\end{array}$ & $\begin{array}{l}\text { Zimbabwe } \\
\text { Zimbabwe }\end{array}$ & $\begin{array}{l}(18) \\
(18)\end{array}$ \\
\hline CD4 & C868T & $\begin{array}{l}\text { Decrease } \\
\text { No effect }\end{array}$ & $\begin{array}{l}\text { Infants } \\
\text { Mothers }\end{array}$ & $\begin{array}{l}\text { Kenya } \\
\text { Kenya }\end{array}$ & $\begin{array}{l}(19) \\
(19)\end{array}$ \\
\hline CCL3 & CCL3L1 & Low GCN increased & Mothers and infants & South Africa & $(20,21)$ \\
\hline FCGR2A & rs1801274 & $\begin{array}{l}\text { No effect } \\
\text { Increased }\end{array}$ & $\begin{array}{l}\text { Mothers } \\
\text { Infants }\end{array}$ & $\begin{array}{l}\text { Kenya } \\
\text { Kenya }\end{array}$ & $\begin{array}{l}(22) \\
(23)\end{array}$ \\
\hline FCGR3A & rs396991 & Increased & Mothers & Kenya & $(22)$ \\
\hline HLA class I & $\begin{array}{l}\text { Concordance between a mother } \\
\text { and her infant and homozygosity } \\
\text { of the maternal HLA } \\
\mathrm{B}^{*} 18 \\
\mathrm{~B}^{*} 44 \\
\mathrm{~A}^{*} 02 / 6802 \\
H L A-G 14 \text { bp insertion }\end{array}$ & $\begin{array}{l}\text { Protect } \\
\text { Protect } \\
\text { Protect } \\
\text { Protect }\end{array}$ & $\begin{array}{l}\text { Infants } \\
\text { Infants } \\
\text { Mothers and infants } \\
\text { Infants }\end{array}$ & $\begin{array}{l}\text { Kenya } \\
\text { Kenya } \\
\text { Cameroon } \\
\text { Kenya } \\
\text { Zambia }\end{array}$ & $\begin{array}{l}(25) \\
(26) \\
(27) \\
\text { Segat et al., } 2014\end{array}$ \\
\hline HLA class II & $\begin{array}{l}\text { DRB concordance between mother and child } \\
\text { DPAl, DPBl and DQB1 concordance }\end{array}$ & $\begin{array}{l}\text { Increased } \\
\text { No effect }\end{array}$ & $\begin{array}{l}\text { Mothers and infants } \\
\text { Mothers and infants }\end{array}$ & $\begin{array}{l}\text { Kenya } \\
\text { Kenya }\end{array}$ & $\begin{array}{l}(28) \\
(28)\end{array}$ \\
\hline
\end{tabular}

GCN: Gene copy number in diploid genome. 
of transmission of HIV, and most of the breast milk factors were associated with a positive effect on the MTCT of HIV-1.49 The binding of sTLR2 to HIV-1 proteins in HIV-1 infected mother breast milk prevent a TLR2-dependent increase in chemokine receptor 5 expression, thus resulting in significant reduction of HIV-1 infection. ${ }^{50}$ The concentration of erythropoietin, a factor with trophic effects on infant gut epithelia studied within a cohort of antiretroviralnaïve HIV infected Tanzanian women, suggest a protective effect against MTCT. ${ }^{51}$ HIV gag -specific IFN- $\gamma$ cellular immune responses from breastmilk of these Tanzanian were prevalent and may contribute to protection from early HIV transmission. In general breast milk cellular responses were potentially influential in decreasing mother-to-child transmission of viruses, ${ }^{52}$ Although Lyimo et al. (2012) have shown that breast milk contains innate factors with divergent activity against cellfree and cell associated HIV-1 in vitro and may contribute to infant infection during breastfeeding. ${ }^{53}$

Bode et al. (2012) showed within a Zambian cohort of HIV-infected women and their infants that higher concentrations of non-3'-SL HMOs (3'-sialyllactose human milk oligosaccharide) were associated with protection against postnatal HIV transmission independent of higher plasma and breast-milk HIV RNA and lower CD4 counts. ${ }^{54}$ Controversially, in a study from the same country, Galectin-3 Binding Protein (Gal3BP) concentrations were significantly associated with the MTCT of HIV-1, but dependently of the milk and plasma HIV load and CD4+ cell counts. ${ }^{55}$

The quantitative mass spectrometry analysis, used by Mangé et al. (2013) to analyse the skim milk proteome have reported that elevated concentrations in breast milk of $\beta 2$-microglobulin and S100A9 were associated with mother-tochild transmission of HIV-1, and the statistics showed that $\beta 2$-microglobulin correlated with milk and plasma HIV viral load and CD4+ cell count, whereas S100A9 correlated with the estimated timing of infection of the infant through breastfeeding. 56

\section{Other host molecular con- stituents potentially affect MTCT: vitamins and cytokines}

The role of vitamins and cytokines was also investigated (Table 2). ${ }^{39,49-51,54-60}$
Vitamin A, with its multiple roles in epithelial, reproductive and immune function, has been evaluated as potential elements for preventing MTCT. Semba et al. (1994) found a statistically significant correlation between vitamin A deficiency and MTCT rates in 338 HIV-infected women in Malawi, speculating that vitamin A deficiency may compromise the epithelial integrity of tissues in the vaginal mucosa and mammary glands. This finding suggests then a link between vitamin A deficiency and an increased risk of infant exposure to HIV during vaginal delivery. ${ }^{48,57}$ Later on, this was not confirmed by other studies from the developped countries. ${ }^{61,62} \mathrm{~A}$ Cochrane Review on vitamin A supplementation and MTCT of HIV was published in 2011, by Wiysonge et al. including all studies performed till September 2010. Five randomized, placebo-controlled studies were included, among which four focused on antenatal vitamin A supplementation, in of 3033 HIV-infected women. The fifth study focused on post-natal vitamin A supplementation and enrolled 4495 HIV-infected women. The included studies were conducted in Zimbabwe, South Africa, Malawi and Tanzania, and rates of vitamin A deficiency were $31-51 \%$. The authors

Table 2. Impact of other host factors in the mother-to-child transmission (MTCT).

\begin{tabular}{|c|c|c|c|c|c|}
\hline Molecules & Aspects & $\begin{array}{l}\text { Effect } \\
\text { on MTCT }\end{array}$ & $\begin{array}{l}\text { Sample } \\
\text { type }\end{array}$ & $\begin{array}{l}\text { Population/ } \\
\text { Country }\end{array}$ & References \\
\hline HIV-specific IgM & Lack of concentration at 18 months in breast milk & Increased & Mothers & Rwanda & (49) \\
\hline sTLR2 in breast milk & I & Reduced & Mothers & Nigeria and Canada & (50) \\
\hline Erythropoietin & Hign concentration in breastmilk & Reduced & Mothers & Tanzania & (51) \\
\hline non-3 -SL HMOs & High concentration in breastmilk & Reduced & Mothers & Zambia & $(54)$ \\
\hline Galectin-3 binding protein & High concentration & Increased & Mothers & Zambia & (55) \\
\hline$\beta 2$-microglobulin and S100A9 & High concentration in breastmilk & Increased & Mothers & South africa & $(56)$ \\
\hline Vitamin A & $\begin{array}{l}\text { Deficiency } \\
\text { Supplementation }\end{array}$ & $\begin{array}{l}\text { Increased } \\
\text { Increased }\end{array}$ & $\begin{array}{l}\text { Mothers } \\
\text { Mothers }\end{array}$ & $\begin{array}{l}\text { Malawi } \\
\text { Zimbabwe, } \\
\text { South Africa, } \\
\text { Malawi and Tanzania }\end{array}$ & $\begin{array}{l}(57) \\
(58,59)\end{array}$ \\
\hline Vitamin D & Low concentration & Increased & Mothers & Tanzania & $(60)$ \\
\hline $\begin{array}{l}\text { IL-4, IL-5, IL-6, IL-7, IL-9, } \\
\text { eotaxin, and IL-1Ra }\end{array}$ & High concentration in placental plasma & $\begin{array}{l}\text { Increased } \\
\text { in utero and } \\
\text { not postpartum }\end{array}$ & Mothers & Malawi & (39) \\
\hline
\end{tabular}

Table 3. Viral genetics may influence the outcome of the mother-to-child transmission (MTCT).

\begin{tabular}{|c|c|c|c|c|}
\hline Subtypes/aspects & Effect on MTCT & Sample type & Population/Country & References \\
\hline Inter subtype recombinant within the LTR & Increased & Mothers & Tanzania & (63) \\
\hline Subtypes A, C and D & Decreased & Mothers & Tanzania & (63) \\
\hline Subtypes A and D & No effect & Mothers & Kenya & (68) \\
\hline Other variants and subtype $\mathrm{C}$ & Increased & Mothers and infants & Malawi; Tanzania & $(64,69)$ \\
\hline Subtypes A and D & Decreased & Mothers and infants & Malawi; Tanzania & $(64,69)$ \\
\hline Subtype D & Increased & Mothers & Kenya & $(65)$ \\
\hline Subtype A & Decreased & Mothers & Kenya & (65) \\
\hline CXCR4-using viruses & Increased & Mothers & Uganda & (66) \\
\hline
\end{tabular}


reported that even in regions where vitamin A deficiency is a public health concern, vitamin A supplementation for prevention of prenatal MTCT is not recommended. ${ }^{58}$ Finally a recent review done on the Vitamin A supplementation for the reduction of the risk of mother-to-child transmission of HIV, reported that early observational studies found an association between vitamin A deficiency and increased rates of MTCT of HIV. However, another did not find a benefit for vitamin A in decreasing MTCT rates. ${ }^{59}$

Low maternal vitamin D level $(<32$ $\mathrm{ng} / \mathrm{mL}$ ) has been shown to be associated with a $50 \%$ higher risk of MTCT of HIV at 6 weeks in Tanzanian women. Vitamin D supplementation could prove to be an inexpensive method of reducing the burden of HIV infection and death among children. ${ }^{60}$

Cytokines, soluble cell-signaling proteins, are important in regulating innate and acquired immunity in inflammatory and infectious diseases. They are major controllers of HIV replication but represent, at the same time, a target for viral-induced immune dysregulation, no study has been done on African populations regarding SNPs in cytokine gene and MTCT, nevertheless in 2012 Kumar et al. found that in Malawi women elevated cytokine levels (IL-4, IL-5, IL-6, IL-7, IL-9, eotaxin, and IL-1Ra) in placental plasma were associated with in utero and not intrapartum MTCT. 39

\section{Viral genotypes may influence the outcome of the MTCT}

Viral genotype and intersubtype recombination may influence the rate and/or timing of mother-to-child HIV-1 transmission that is why it is important to know whether selective pressures influence the transmission. Some findings stipulate that the viral subtypes influence the transmission of HIV1 from mother to child. Intersubtype recombinant genomes, and especially recombination within the LTR, might render HIV-1 more fit for transmission via breast milk in comparison with non-recombinant subtypes A, C, and D. ${ }^{63}$ A significant difference in the distribution of transmission time according to subtype and a higher proportion of HIV-1 with subtype C env (C-env) transmitted in utero than HIV-1 with subtype A env (A-env), subtype D env (D-env), or both combined was reported by Renjifo et al. (2004), ${ }^{64}$ also Yang et al. (2003) found that MTCT appears to be more common among mothers infected with subtype D compared with subtype A. ${ }^{65}$ A study in 2009 supports these data in non-B subtype virus infection, here the authors demonstrate that in five Ugandan mother-child pairs X4 and R5X4 viruses were transmitted before, during or shortly after delivery, and thus, establish vertical transmission as an important source of CXCR4-using viruses in infants. ${ }^{66}$ But a contrary study have reported that phylogenetic tree topologies argue against selection processes as the major mechanism driving mother-to-child transmission but support the hypothesis that virus variability is mainly driven by the inoculum level and/or exposure time. ${ }^{67}$ Another study did not find any association between clades A and D and either frequency or mode of vertical transmission. ${ }^{68}$

The first studies comparing the genetic sequences of viruses from mother and child showed that the maternal viral population is more heterogeneous than that of the child. ${ }^{69}$ If only a limited number of variants are originally transmitted and/or are initially replicating in the child is still a matter of discussion. On the one hand it was shown that a minor viral variant of the mother constituted the dominant variant in the child, on the other hand a major maternal variant could be detected in the child. ${ }^{69,70}$ If selective infection occurs, an association between viral phenotype and transmission could exist, however, all viral phenotypes, though to a different proportion, were detected in vertically infected children. On the other hand it was shown that selection may occur in relation to different transmission routes, in utero vs. intra partum. Indeed, a major maternal virus variant as well as subtype $C$ variants compared to $\mathrm{A}$ and $\mathrm{D}$ were associated with in utero transmission. ${ }^{65,70}$

As shown, some studies share the hypothesis that the genetic variation of the HIV1 can drive the MTCT and some are against, but it is noted that in most of the studies the number of mother-child pairs was small and information concerning the infection time of the infants was lacking. These limitations should be taken into account for future studies (Table 3).

\section{Conclusions}

Many studies have established that host genetic factors are important determinants of HIV-1 MTCT. However, it is clear that no single genetic variant is a dominant factor. Some limitations are to be pointed out. Most of the published studies were done on the same population (Kenyan, Tanzanian, South African....) and this underlines the need to identify different prognostic markers according to genetic background. Some of the studies were not case-control, which makes them difficult to assess or dis- sect confounders in the context of prevention which may lead to an apparent inversion of expected associations. One limitation was the population size studied: inclusion of small number of mother-child pairs with incomplete sets of relevant data, limits the power to detect the effects of common and rare genetic variants. There is need to consider both the genetic profiles of the mothers as well as those of exposed children to avoid distortions between the population parameters for genetic polymorphisms and susceptibility to HIV-1 MTCT.

There is also a need to look at the effect of co-infections when studying these polymorphisms in the case of Sub Saharan countries. For future research, the recommendation is to study a larger population size, different ethnicities, looking at the effect of all described AIDS related genes (all together) including those involved in innate immunity, using appropriate control groups and including other factors such as the presence of co-infections, the age of the mother, the anti-retroviral drugs administered and so on. These studies will benefit the development of a vaccine suitable for all population background.

\section{References}

1. Temgoua EM, Nkenfou CN, ZoungKanyi AC, et al. Hiv-1 early infant diagnosis is an effective indicator of the prevention of mother-to-child transmission program performance: experience from Cameroon. Curr HIV Res 2015;13:2861.

2. CNLS (Comité National de Lutte contre le SIDA). Rapport annuel 2014 des activités de lutte contre le VIH/SIDA et les IST au Cameroun. 2014. Available from: http://www.cnls.cm/ docs/ Rapport_Annuel_CNLS_2014.pdf.

3. CNLS (Comité National de Lutte contre le SIDA). Rapport national de suivi de la déclaration politique sur le VIH/SIDA Cameroun Global AIDS Response Progress (GARP). 2014. Available from : http://www.cnls.cm/ docs/Rapport_GARP_2014_Juin_2015 CNLS.pdf.

4. Healy M. Government shuts down AIDS vaccine trial-latimes.com. Los Angeles Times (Los Angeles: Tribune Co). ISSN 0458-3035. 25 April 2013.

5. McMichael A, Picker LJ, Moore JP, et al. Another HIV vaccine failure: where to next? Nat Med 2013;19:1576-7.

6. Sekaly R. The failed HIV Merck vaccine study: a step back or a launching point for future vaccine development? J Exp Med 2008;205:7-12. 
7. Fokam, J, Salpini R, Santoro MM, et al. Drug resistance among drug-naive and first-line antiretroviral treatment-failing children in Cameroon. Pediatr Infect Dis J 2011;30:1062-8.

8. Luzuriaga K, Sullivan JL. Pediatric HIV-1 infection: advances and remaining challenges. AIDS Rev 2000;4:216.

9. WHO. The global HIV/AIDS epidemic. 2015. Available from: https://www.aids. gov/hiv-aids-basics/hiv-aids-101/global-statistics/. Accessed on 13 March 2016.

10. CNLS (Comité National de Lutte contre le SIDA). Rapport annuel 2013 de la lutte contre le VIH/SIDA et les IST au Cameroun. Cameroun 2002. 2013. Available from: http://www.cnls. cm/docs/Rapport_annuel_2013.pdf.

11. Singh KK, Hughes MD, Chen J, et al. Associations of chemokine receptor polymorphisms with HIV-1 mother-tochild transmission in sub-saharan Africa: possible modulation of genetic effects by antiretroviral. J Acquir Immune Defic Syndr 2008;49:259-65.

12. Pedersen BR, Kamwendo D, Blood M, et al. CCR5 haplotypes and mother-tochild HIV transmission in Malawi. PLoS One 2007;2:e838.

13. John GC, Bird T, Overbaugh J, et al. CCR5 promoter polymorphisms in a Kenyan perinatal human immunodeficiency virus type 1 cohort: association with increased 2-year maternal mortality. J Infect Dis 2001;184:89-92.

14. Mabuka JM, Mackelprang RD, Lohman-Payne B, et al. CCR2-64I polymorphism is associated with lower maternal HIV-1 viral load and reduced vertical HIV-1 transmission. J Acquir Immune Defic Syndr 2009;51:235-7.

15. Brouwer KC, Lal RB, Mirel LB, et al. Polymorphism of Fc receptor IIa for $\mathrm{IgG}$ in infants is associated with susceptibility to perinatal HIV-1 infection. AIDS 2004;18:1187-9.

16. Katz DA, John-Stewart GC, Richardson BA, et al. CCR5, RANTES, and SDF-1 polymorphisms and mother-to-child HIV-1 transmission. Int J Immunogenet 2010;37:301-5.

17. John CG, Chrrousseau C, Dong T, et al. Maternal SDF1 3'A polymorphism is associated with increased perinatal human immunodeficiency virus type 1 transmission. J Virol 2000;74:5736-9.

18. Boily-Larouche G, Iscache A, Zijenah LS, et al. Functional genetic variants in DC-SIGNR are associated with mother to-child transmission of HIV-1. PLoS One 2009;4:e7211.

19. Choi RY, Farquhar C, Juno J, et al.
Infant CD4 C868T polymorphism is associated with increased human immunodeficiency virus (HIV-1) acquisition. Clin Exp Immunol 2010;160:461-5.

20. Meddows-Taylor S, Donninger SL, Paximadis M, et al. Reduced ability of newborns to produce CCL3 is associated with increased susceptibility to perinatal human immunodeficiency virus 1 transmission. J Gen Virol 2006;87: 2055-65.

21. Kuhn L, Schramm DB, Donninger S, et al. African infants' CCL3 gene copies influence perinatal HIV transmission in the absence of maternal nevirapine. AIDS 2007,21:1753-61.

22. Milligan C, Richardson BA, JohnStewart G, et al. FCGR2A and FCGR3A genotypes in HIV mother-tochild transmission. Open Forum Infect Dis 2015;2:fv149.

23. Brouwer KC, Yang C, Parekh S, et al. Effect of CCR2 chemokine receptor polymorphism on HIV type 1 motherto-child transmission and child survival in Western Kenya. AIDS Res Hum Retroviruses 2005;21:358-62.

24. Mackelprang RD, John-Stewart G, Carrington M, et al. Maternal HLA homozygosity and mother-child HLA concordance increase the risk of vertical transmission of HIV-1. J Infect Dis 2008;197:1156-61.

25. Farquhar C, Rowland-Jones S, MboriNgacha D, et al. Human leukocyte antigen (HLA) B*18 and protection against mother-to-child HIV type 1 transmission. AIDS Res Hum Retroviruses 2004;20:692-97.

26. Nkenfou CN, Nemes E, Mekue L, et al. Human leucocyte antigen class I diversity among human immunodeficiency virus exposed negative and positive children in Cameroon. J AIDS Clin Res 2015;6:439.

27. MacDonald K, Embree JE, Nagelkerke $\mathrm{N}$, et al. The HLA A2/6802 supertype is associated with reduced risk of perinatal human immunodeficiency virus type 1 transmission. J Infect Dis 2001;183: 503-6.

28. Luo M, Embree J, Ramdahin S, et al. HLA class II antigens and their interactive effect on perinatal mother-to-child HIV-1 transmission. PLoS One 2015; 10:e0126068.

29. Buseyne F, Janvier G, Teglas JP, et al. Impact of heterozygosity for the chemokine receptor CCR5 32-bp-deleted allele on plasma virus load and CD4 $\mathrm{T}$ lymphocytes in perinatally human immunodeficiency virus-infected children at 8 years of age. J Infect Dis 1998;178:1019-23.
30. Kaur G, Mehra N. Genetic determinants of HIV-1 infection and progression to AIDS: susceptibility to HIV infection. Tissue Antigens 2009;73:289-301.

31. Piacentini L, Biasin M, Fenizia C, et al. Genetic correlates of protection against HIV infection: the ally within. J Inter Med 2009;265:110-24.

32. Kostrikis LG, Neumann AU, Thomson $\mathrm{B}$, et al. A polymorphism in the regulatory region of the CC-chemokine receptor 5 gene influences perinatal transmission of Human Immunodeficiency Virus type 1 to African-American infants. J Virol 1999;73:10264-71.

33. Mangano A, Prada F, Roldan A, et al. Distribution of CCR-5 delta32 allele in Argentinian children at risk of HIV-1 infection: its role in vertical transmission. AIDS 1998;12:109-10.

34. Joubert BR, Franceschini N, Mwapasa $\mathrm{V}$, et al. Regulation of CCR 5 expression in human placenta: insights from a study of mother-to-child transmission of HIV in Malawi. PLoS One 2010;5:e212.

35. Teglas JP, N'Go N, Burgard $M$ et al. CCR2B-64I chemokine receptor allele and mother-tochild HIV-1 transmission or disease progression in children. J Acquir Immune Defic Syndr 1999;22: 267-71.

36. Da Silva RC, Segat L, Crovella S. Role of DC-SIGN and L-SIGN receptors in HIV-1 vertical transmission. Hum Immunol 2011;72:305-11.

37. Cocchi F, DeVico AL, Garzino-Demo $A$, et al. Identification of RANTES, MIP- $1 \alpha$, and MIP- $1 \beta$ as the major HIVsuppressive factors produced by CD8+ T cells. Science 1995;270:1811-5.

38. Liu M, Guo S, Hibbert JM, et al. CXCL10/IP-10 in infectious diseases pathogenesis and potential therapeutic implications. Cytokine Growth Factor Rev 2011;22:121-30.

39. Kumar SB, Rice CE, Milner DA, et al. Elevated cytokine and chemokine levels in the placenta are associated with in utero HIV-1 mother-to-child transmission. AIDS 2012;26:685-94.

40. Musolino M, Naldi N, Bortesi B, et al. Immunoglobulin $\mathrm{G}$ fragment $\mathrm{C}$ receptor polymorphisms and clinical efficacy of trastuzumab-based therapy in patients with HER-2/neu-positive metastatic breast cancer. J Clin Oncol 2008;26: 1789-96.

41. Bruhns P, Iannascoli B, England P, et al. Specificity and affinity of human Fc gamma receptors and their polymorphic variants for human IgG subclasses. Blood 2009;113:3716-25.

42. Parham P, Ohta T. Population biology 
of antigen presentation by MHC class I molecules. Science 1996;272:67-74.

43. O’Brien SJ, Gao X, Carrington M. HLA and AIDS: a cautionary tale. Trends Mol Med 2001;7:379-81.

44. Carrington M, O’Brien SJ. The influence of HLA genotype on AIDS. Annu Rev Med 2003; 54:535-51.

45. Polycarpou A, Ntais C, Korber BT, et al. Association between maternal and infant class I and II HLA alleles and of their concordance with the risk of perinatal HIV type 1 transmission. AIDS Res Hum Retroviruses 2002;18:741-6.

46. Luo M, Czarnecki C, Ramdahin S, et al. HLA-G and mother-child perinatal HIV transmission. Hum Immunol 2013;74: 459-63.

47. Joubert BR, Lange EM, Franceschini N, et al. A whole genome association study of mother-to-child transmission of HIV in Malawi. Genome Med 2010;2:17.

48. Aldrovandi GM, Kuhn L. What infants and breasts can teach us about natural protection from HIV infection. J Infect Dis 2010;202:S366-70.

49. Van de Perre P, Simonon A, Karita E, et al. Infective and anti-infective properties of breast milk from HIV-1-infected women. Lancet 1993;341:914-8.

50. Henrick BM, Yao XD, Drannik AG, et al. Soluble toll-like receptor 2 is significantly elevated in HIV-1 infected breast milk and inhibits HIV-1 induced cellular activation, inflammation and infection. AIDS 2014;28:2023-32.

51. Arsenault JE, Webb AL, Koulinska IN, et al. Breast milk erythropoietin is associated with reduced risk of mother-tochild transmission of HIV. J Infect Dis 2010;202:370-3.

52. Lohman-Payne B, Slykera JB, Moore S, et al. Breast milk cellular HIV-specific interferon $\gamma$ responses are associated with protection from peripartum HIV transmission. AIDS 2012;26:2007-16.

53. Lyimo MA, Mosi MN, Housman ML, et al. Breast milk from Tanzanian women has divergent cffects on cellfree and cell-associated HIV-1 infection in vitro. PLoS One 2012;7:e43815.

54. Bode L, Kuhn L, Kim HY et al. Human milk oligosaccharide concentration and risk of postnatal transmission of HIV through breastfeeding. Am J Clin Nutr 2012;96:831-9.

55. Chan CS, Kim HY, Autran MC, et al. Human milk galectin-3 binding protein and breastfeeding-associated HIV transmission. Pediatr Infect Dis J 2013;32: e473-5.

56. Mangé A, Tuaillon E, Viljoen J, et al. Elevated concentrations of milk $\beta 2$ microglobulin are associated with increased risk of breastfeeding transmission of HIV-1 (Vertical Transmission Study). J Proteome Res 2013;12:5616-25.

57. Semba RD, Miotti PG, Chiphangwi JD. Maternal vitamin A deficiency and mother-to-child transmission of HIV-1. Lancet 1994;34:1593-7.

58. Wiysonge CS, Shey M, Kongnyuy EJ, et al. Vitamin A supplementation for reducing the risk of mother-to-child transmission of HIV infection. Cochrane Database Syst Rev 2011;19:CD003648.

59. McHenry MS, Apondi E, Vreeman RC. Vitamin A supplementation for the reduction of the risk of mother-to-child transmission of HIV. Expert Rev Anti Infect Ther 2015;13:821-4.

60. Mehta S, Hunter DJ, Mugusi FM, et al. Perinatal outcomes, including motherto-child transmission of HIV, and child mortality and their association with maternal vitamin D status in Tanzania. J Infect Dis 2009;200:1022-30.

61. Burger H, Kovacs A, Weiser B. Maternal serum vitamin A levels are not associated with mother-to-child transmission of HIV-1 in the United States. J Acquir Immune Defic Syndr Hum Retrovirol 1997;14:321-6.

62. Burns DN, FitzGerald G, Semba R. Vitamin A deficiency and other nutritional indices during pregnancy in human immunodeficiency virus infection: prevalence, clinical correlates, and out- come. Women and infants transmission study group. Clin Infect Dis 1999;29: 328-34.

63. Koulinska IN, Villamor E, Msamanga G, et al. Risk of HIV-1 transmission by breastfeeding among mothers infected with recombinant and non recombinant HIV-1 genotypes. Virus Res 2006;120:191-8.

64. Renjifo B, Gilbert P, Chaplin B, et al. Preferential in utero transmission of HIV-1 subtype C as compared to HIV-1 subtype A or D. AIDS 2004;18:162936.

65. Yang $C$, Li M, Newman RD, et al. Genetic diversity of HIV-1 in western Kenya: subtype-specific differences in mother-to-child transmission. AIDS 2003;17:1667-74.

66. Huang W, Eshleman SH, Toma J, et al. Vertical transmission of X4-tropic and dual-tropic HIV-1 in five Ugandan mother-infant pairs. AIDS 2009;23: 1903-8.

67. Verhofstede C, Demecheleer E, Cabooterhttp://jvi.asm.org/content/77/5 /3050.full - aff-1 ND, et al. Diversity of the human immunodeficiency virus type 1 (HIV-1) env sequence after vertical transmission in mother-child pairs infected with HIV-1 subtype A. J Virol 2003,77:3050-7.

68. Murray MCM, Embree JE, Ramdahin SG, et al. Effect of human immunodeficiency virus (HIV) type 1 viral genotype on mother-to-child transmission of HIV-1. J Infect Dis 2000;181:746-9.

69. Kwiek JJ, Russell ES, Dang KK, et al. The molecular epidemiology of HIV-1 envelope diversity during HIV-1 subtype $\mathrm{C}$ vertical transmission in Malawian mother-infant pairs. AIDS 2008;22: 863-71.

70. Wike CM, Korber BT, Daniels MR, et al. HIV-1 sequence variation between isolates from mother-infant transmission pairs. AIDS Res Hum Retroviruses 1992;8:1297-300. 